\title{
ОСОБЛИВОСТІ ПЕРЕБІГУ ХРОНІЧНОГО ОБСТРУКТИВНОГО ЗАХВОРЮВАННЯ ЛЕГЕНЬ В ОСІБ СТАРШОГО ВІКУ
}

\author{
Ю. Г. Богута, Х. Я. Максів, У. П. Гевко, О. П. Мялюк, М. І. Марущак \\ Двнз «Тернопільський державний медичний університет \\ імені І. Я. Горбачевського МОЗ Украӥни" \\ Рівненський державний базовий медичний коледж
}

\begin{abstract}
Отримані дані вказують на те, що хронічне обструктивне захворювання легень в осіб старшого віку часто поєднується з серцево-судинною патологією. Тому первинна профілактика повинна включати основні фактори хронічного обструктивного захворювання легень - тютюнокуріння і часті респіраторні захворювання, вторинна профілактика хронічного обструктивного захворювання легень має бути спрямована на попередження розвитку системних уражень на фоні досліджуваної патології. Враховуючи те, що наше дослідження встановило високу частоту хронічного обструктивного захворювання легень та ішемічної хвороби серця і хронічного обструктивного захворювання легень та гіпертонічної хвороби у пацієнтів обох статей III ступеня тяжкості порушень прохідності дихальних шляхів, проведення просвітницької роботи середнім медичним персоналом має включати профілактику як хронічного обструктивного захворювання легень, так і кардіологічних патологій.
\end{abstract}

\section{FEATURES OF CHRONIC OBSTRUCTIVE PULMONARY DISEASE IN ELDERLY PEOPLE}

\author{
Yu. H. Boguta, H. Ya. Maksiv, U. P. Hevko, O. P. Mialiuk, M. I Maruschak \\ I. Horbachevsky Ternopil State Medical University \\ Rivne State Basic Medical College
}

\begin{abstract}
The data indicate that chronic obstructive pulmonary disease (COPD) in the elderly is often associated with cardiovascular disease. Therefore, primary prevention should concern the main factors of COPD - smoking and frequent respiratory diseases, secondary prevention of COPD should be aimed at systemic lesions development' prophylaxis on the background of study pathology. It was found a high incidence of COPD and coronary heart disease, COPD and hypertension in patients with grade 3 airway disorders, conductsng educational work nurses should include prevention both COPD and cardiac abnormalities.
\end{abstract}

Вступ. Процес демографічного старіння поступово охопив усі розвинуті країни Європи. Сьогодні люди старшого віку значно відрізняються від пенсіонерів минулих років, оскільки вони вступили в надзвичайно складний період життя одночасно з настанням складного періоду в самій країні. Тому на сьогодні літня людина недоотримала багато з того, на що сподівалася і прийшла до старості без матеріальної і духовної опори [1]. Однією з гострих медичних проблем у людей літнього віку $є$ хронічне обструктивне захворювання легень (ХОЗЛ), для якого характерно неповністю зворотне обмеження прохідності дихальних шляхів, що прогресує і пов'язане із запальною відповіддю легень на шкідливі подразники: куріння, забруднення атмосфери, професійні шкідливості [2]. Сучасні дані Всесвітньої організації охорони здоров'я свідчать про те, що близько 210 млн осіб є хворими на ХОЗЛ, а щорічна летальність становить понад 2,75 млн людей. За смертністю досліджувана патологія в усьому світі стоїть поряд із ВІЛ/СНІДом [3].

Метою нашого дослідження було вивчити етіологічні фактори хронічного обструктивного захворювання легень та коморбідність при досліджуваній патології.

У дослідження було включено 64 хворих на ХОЗЛ різного ступеня тяжкості, які перебували на стаціонарному лікуванні у пульмонологічному відділенні Тернопільської університетської лікарні протягом 2015 р. з приводу загострення ХОЗЛ.

() Ю. Г. Богута, Х. Я. Максів, У. П. Гевко, О. П. Мялюк, М. І. Марущак, 2017

26 ISSN 2411-1597. МЕДСЕСТРИНСТВО. 2017. № 2 
У дослідження були включені хворі з ХОЗЛ II, III i IV стадій, які відповідали таким критеріям: госпіталізація в стаціонар з приводу загострення ХОЗЛ; вік >60 років; приріст ОФВ після інгаляції $\beta_{2}$-агоністом короткої дії менше 12 \%. Була проаналізована частота найбільш значущих клінічних станів, які, за даними останніх досліджень, асоціюються зі зростанням ризику смерті у хворих на ХОЗЛ. Для визначення статистичної значущості (р) зміни від вихідного рівня використовували комп'ютерну програму «Statistica 16.0 for Microsoft».

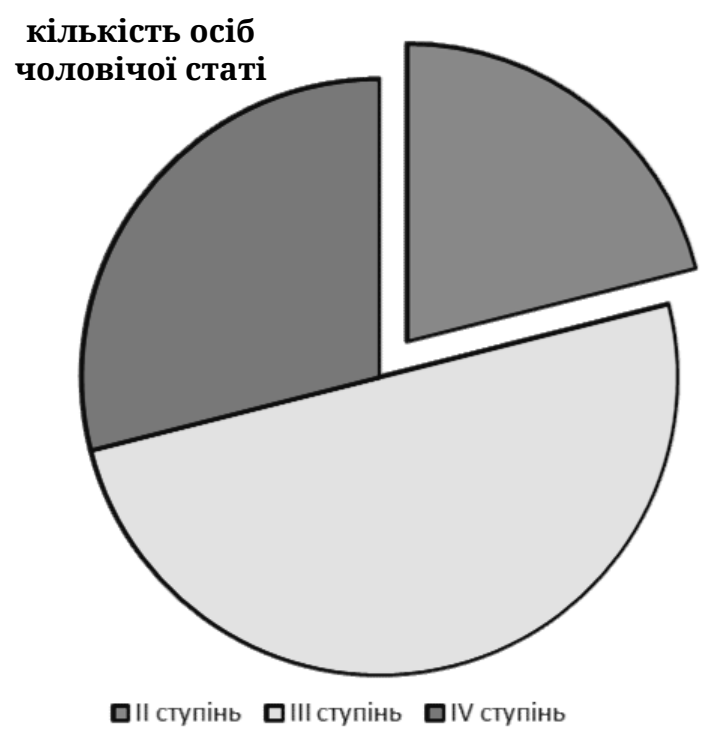

Основна частина. Середній вік хворих коливався від 60 до 78 років. Серед пацієнтів було 38 (59,4 \%) чоловіків і 26 (40,6 \%) жінок. В осіб обох статей найчастіше діагностували ХОЗЛ ІІІ ступеня тяжкості порушень прохідності дихальних шляхів, коли об'єм форсованого видиху за 1 с (ОФВ $\left.{ }_{1}\right)$ становив 30-50 \% від належних (31 пацієнт). Значно рідше виявляли помірний (16 хворих, при ОФВ 1 в межах 50-80 \% від належних) і дуже тяжкий (17 хворих, при ОФВ нижче 30 \% від належних) ступені тяжкості порушень прохідності дихальних шляхів (рис. 1).

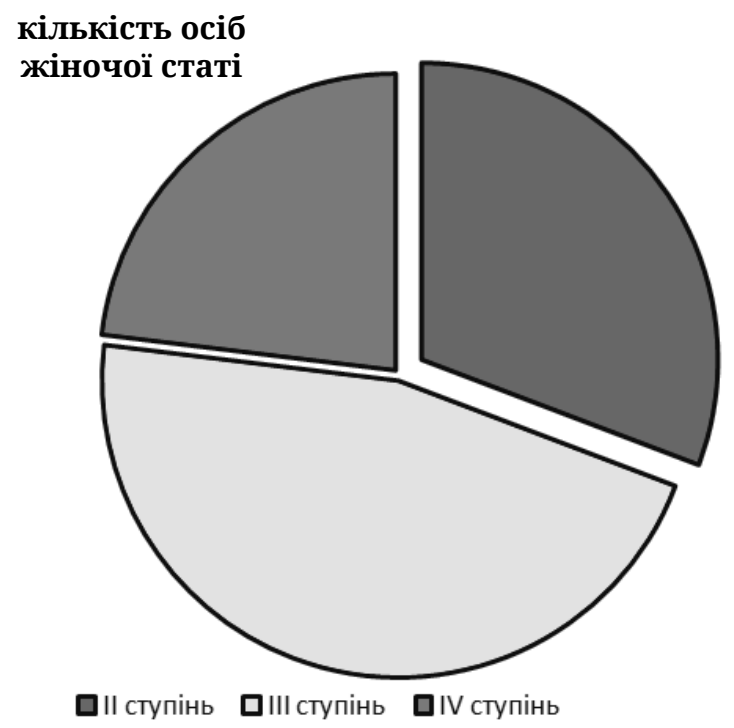

Puc. 1. Розподіл хворих на ХОзЛ залежно від ступеня тяжкості порушень прохідності дихальних шляхів.

При аналізі факторів ризику ХОзЛ враховували куріння, частоту респіраторних інфекцій, обтяжений алергологічний чи сімейний анамнез. Виявлено, що найбільше курять пацієнти чоловічої статі з ХОЗЛ II і III ступенів (рис. 2). Враховуючи малу кількість жінок із ХОЗЛ, які курять, проаналізували ймовірність пасивного куріння. Варто відмітити, що серед включених у дослідження жінок курять близькі родичі, які проживають з ними. Так, пасивне куріння встановлено у 75,0 \% хворих жінок на ХОЗЛ ІІ ступеня тяжкості та у 66,7 \% - на ХОЗЛ III і IV ступенів тяжкості.

На респіраторні захворювання протягом останнього року хворіли усі проанкетовані, при цьому жінки хворіли значно частіше (3-5 разів), ніж чоловіки (1-3 рази).

Аналіз алергологічного анамнезу показав, що він $\epsilon$ обтяженим у 79,7 \% хворих, практично однаковою мірою як у жінок, так і чоловіків. Отримані дані щодо сімейного анамнезу свідчать про те, що 29,7 \% хворих мають чи мали родичів зі сторони матері чи батька, які хворіли на часті респіраторні захворювання з озна- ками бронхообструкції, у 10,9 \% пацієнтів хворіють діти на ХОЗЛ.

Підбиваючи підсумки першого етапу дослідження, можна зазначити, до основних факторів ризику розвитку ХОЗЛ належать тютюнокуріння й часті респіраторні захворювання.

Останніми роками все частіше зазначаються екстрапульмональні ефекти ХОЗЛ, які зумовлюють розвиток інших патологій, що обтяжують перебіг деяких захворювань, які мають спільні фактори ризику. Тому проаналізували коморбідні стани у хворих на хОЗЛ та визначили їх зв'язок із основними факторами ризику - тютюнокурінням й частими респіраторними захворюваннями.

Встановлено, що 7,8 \% пацієнтів із ХОЗЛ не мали супутньої патології, тоді як 92,2 \% обстежених хворих, окрім ХОЗЛ, страждали ще на одне й більше захворювань. Отримані дані в дослідженні збігаються 3 наведеними результатами J. G. van Manen зі співавт., які виявили у понад 50 \% пацієнтів із ХОЗЛ супутню 


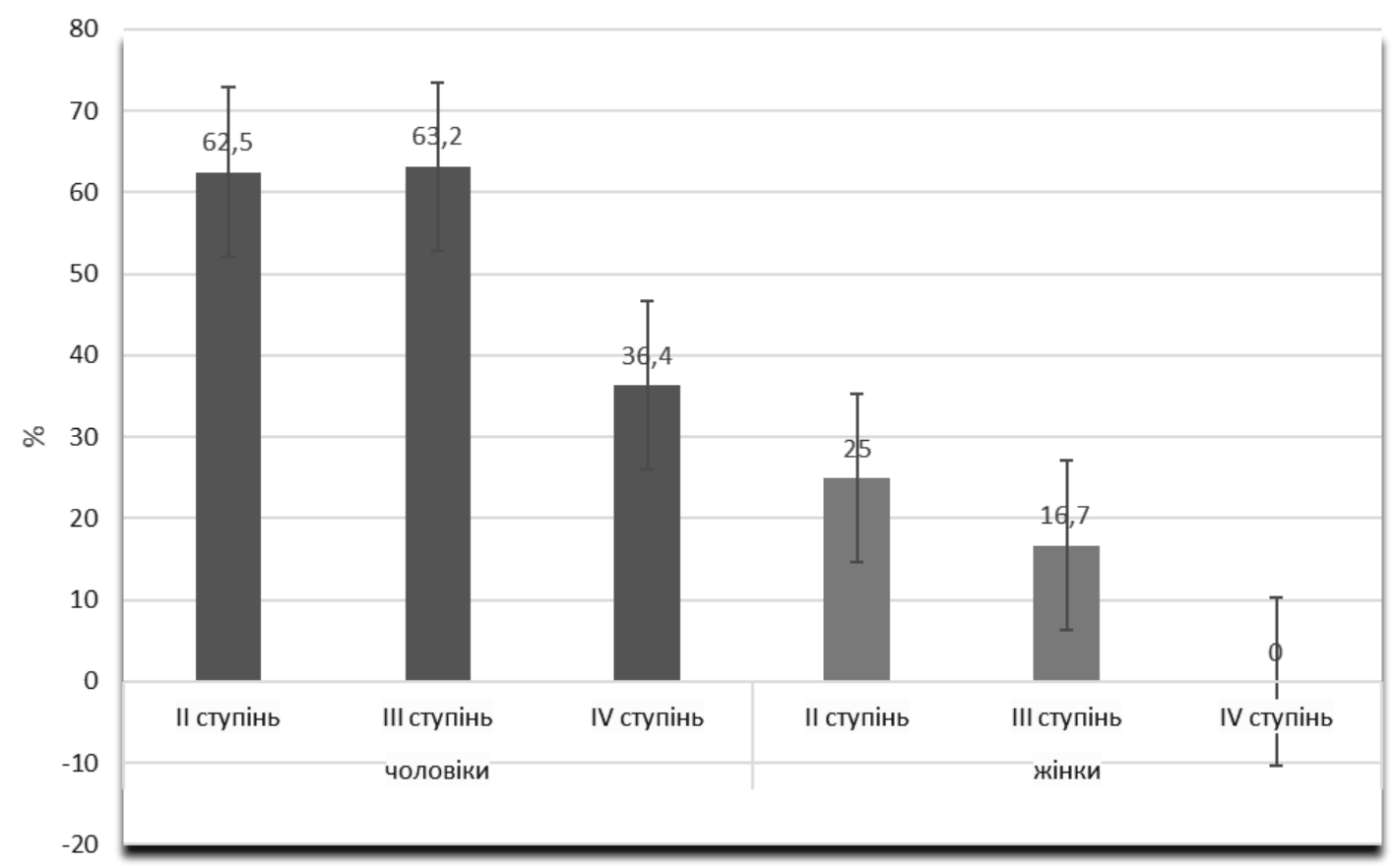

Puc. 2. Гендерний розподіл хворих на ХОЗЛ, які курять.

патологію [4]. Якщо врахувати, що у наше дослідження були включені пацієнти віком понад 60 років, відсоток пацієнтів з супутніми патологіями значно вищий. Варто зазначити про відсутність гендерних відмінностей, оскільки супутні стани у хворих на ХОЗЛ спостерігалися у 92,1 \% чоловіків і 92,3 \% жінок (рис. 3).

Аналіз супутньої патології у хворих на ХОЗЛ вказує на переважання серцево-судинної патології. Так, ішемічну хворобу серця реєстрували у 10,2 \% хворих II ступеня тяжкості порушень прохідності дихальних шляхів, у 25,4 \% хворих III ступеня тяжкості та у 15,3 \% хворих IV ступеня тяжкості. Гіпертонічну хворобу серця діаг- ностували, відповідно, у 8,5 \%, 30,5 \% і 22,0 \% хворих на ХОЗЛ. Поєднання цих захворювань спостерігали, відповідно, у 8,5 \%, 16,9 \% і 15,3 \% хворих на ХОЗЛ (рис. 4-6). При аналізі коморбідних станів при ХОЗЛ, у обстежених пацієнтів виявляли також цукровий діабет, захворювання шлунково-кишкового тракту та нирок.

Отримані дані вказують на те, що хронічне обструктивне захворювання легень в осіб старшого віку часто поєднується з серцево-судинною патологією. Тому первинна профілактика повинна включати основні фактори ХОЗЛ - тютюнокуріння і часті респіраторні захворювання, вторинна профілактика ХОЗЛ має

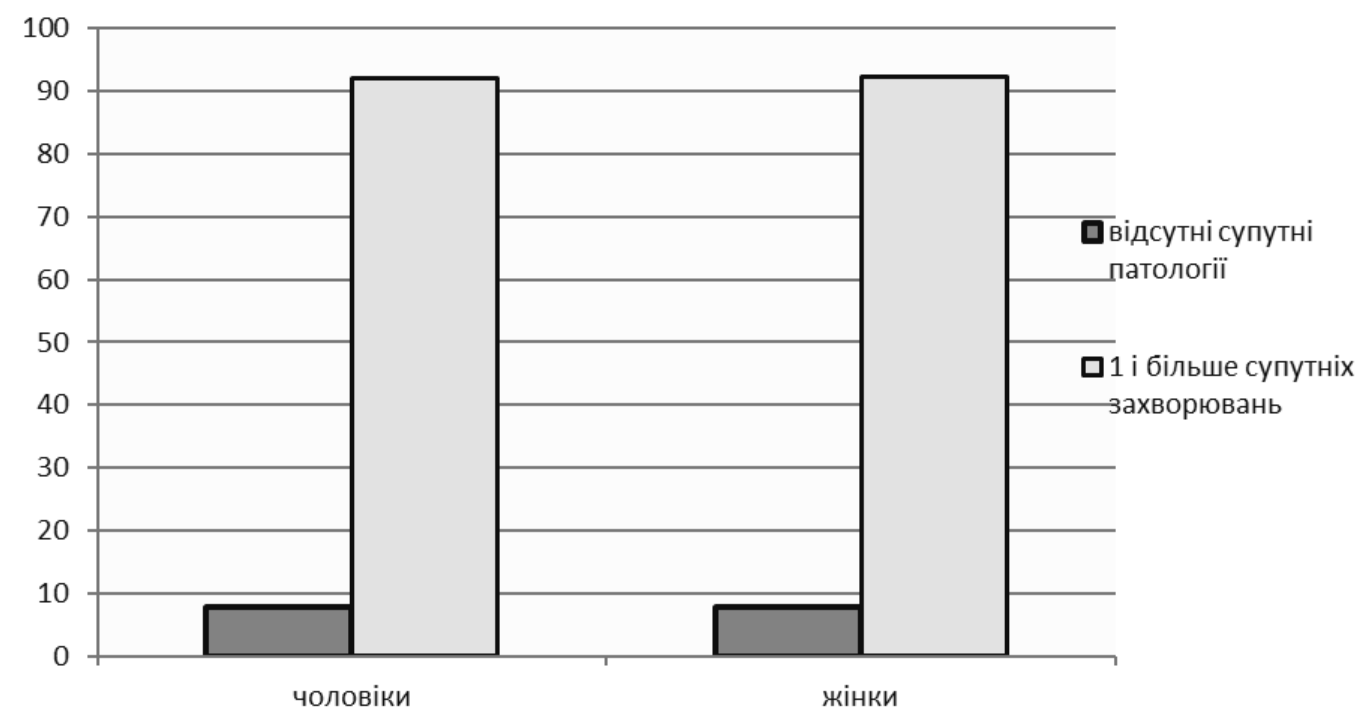

Puc. 3. Поширеність супутніх патологій у хворих на ХОЗЛ, \%. 


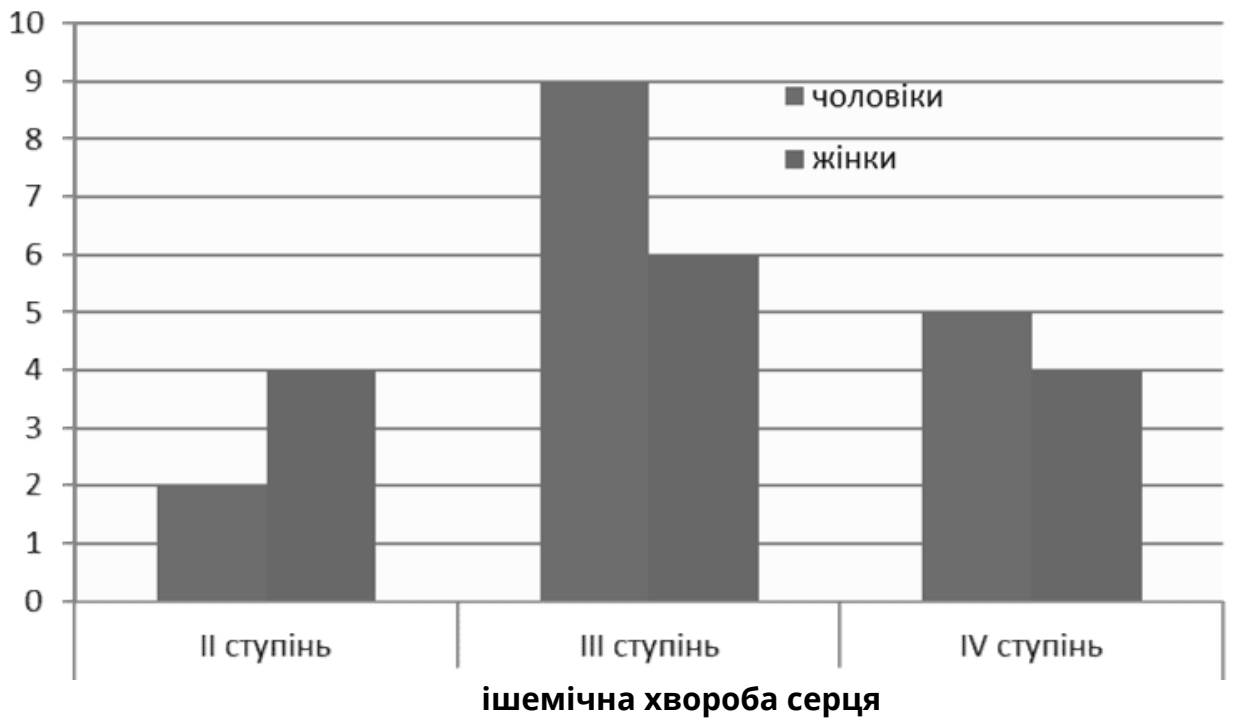

Puc 4. Частота ішемічної хвороби серця у хворих на ХОЗЛ.

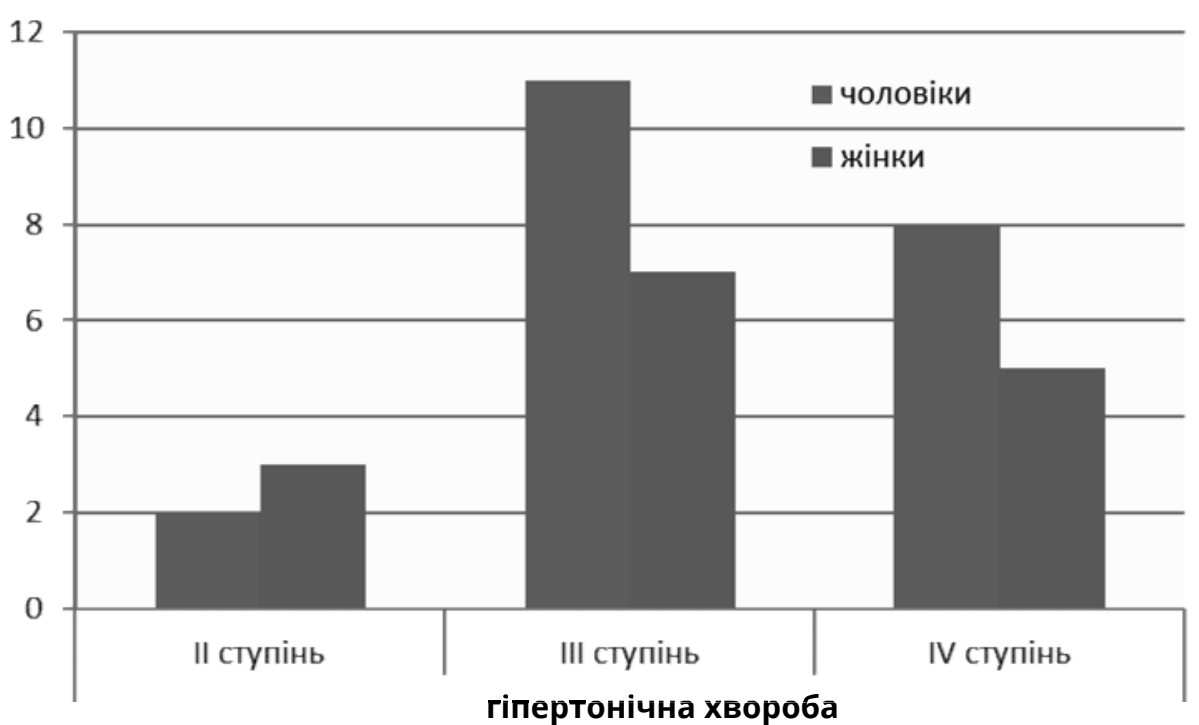

Puc. 5. Частота гіпертонічної хвороби у хворих на ХОЗЛ.

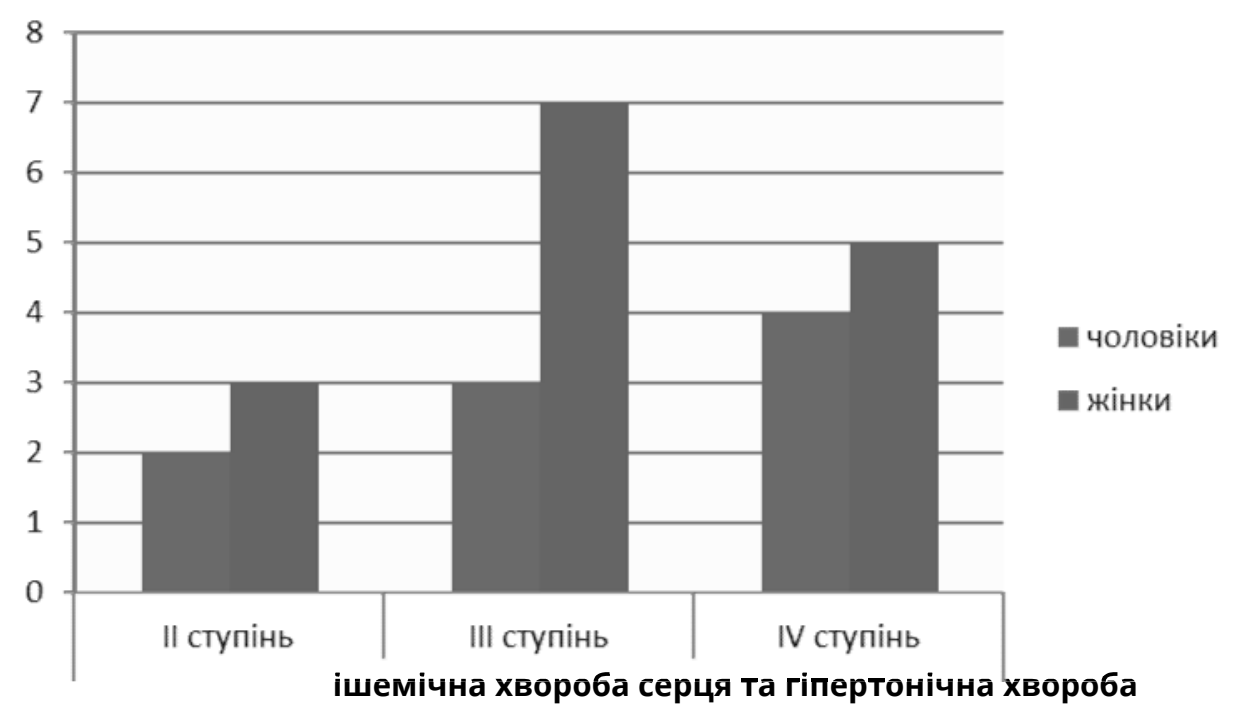

Puc. 6. Частота поєднання ішемічної хвороби серця і гіпертонічної хвороби у пацієнтів із ХОзЛ. 
бути спрямована на попередження розвитку системних уражень на фоні досліджуваної патології. Враховуючи те, що наше дослідження встановило високу частоту ХОЗЛ та ішемічної хвороби серця та ХОЗЛ і гіпертонічної хвороби у пацієнтів обох статей III ступеня тяжкості порушень прохідності дихальних шляхів, проведення просвітницької роботи середнім медичним персоналом має включати профілактику як ХОЗЛ, так і кардіологічних патологій.

Отримані дані збігаються з іншими дослідженнями, які пов'язують підвищення артеріального тиску з тяжкістю дихальної обструкції [5]. Варто зазначити, що спільним фактором ризику для ХОЗЛ і серцевосудинних захворювань може бути загальний фактор куріння, тому найбільша увага медичного персоналу має бути приділена відмові пацієнтів від куріння. Ряд дослідників зазначає, що саме кардіологічні захворювання є причиною смерті серед хворих на ХОЗЛ [6].
Для оцінки самопочуття пацієнтів із коморбідними патологіями ми поставили їм 2 запитання щодо їх фізичного та емоційного станів: 1. Як Ви оцінюєте свій емоційний стан, настрій на сьогодні? 2. Як Ви оцінюєте свій стан здоров'я, фізичний стан на сьогодні?

Свій емоційний стан пацієнти оцінили по-різному, проте жоден із досліджуваних не почував себе на відмінно. Так, пацієнти старшого віку (понад 60 р.) оцінили свій емоційний стан як добрий у 10,9 \% випадків, задовільний - у 25,0 \% випадків, незадовільний -у 9,4\% випадків. Відповідно, пацієнти оцінили свій фізичний стан як добрий у 7,8 \% випадків, задовільний - у 26,6 \% випадків, незадовільний - у 9,4 \% випадків (табл.).

Аналізуючи отримані дані, можна стверджувати, що пацієнти пов'язують свій емоційний стан із фізичним здоров'ям.

Висновки. 1. До основних факторів ризику розвитку й прогресування хронічного обструктивного

Таблиця. Самооцінка емоційного та фізичного станів пацієнта

\begin{tabular}{|c|c|c|c|c|c|}
\hline Запитання & Відмінна & Добра & Задовільна & Незадовільна & Важко відповісти \\
\hline Емоційний стан, настрій на сьогодні & - & 7 & 16 & 6 & 3 \\
\hline Стан здоров'я, свій фізичний стан на сьогодні & - & 5 & 17 & 6 & 4 \\
\hline
\end{tabular}

захворювання легень у пацієнтів старшого віку, чоловічої та жіночої статей, насамперед тютюнокуріння й часті респіраторні захворювання, також впливає обтяжений алергологічний та сімейний анамнез.

2. Пацієнти старшого віку з хронічними обструктивними захворюваннями легень характеризуються значною коморбідністю. Найпоширенішими коморбідними станами у таких хворих $є$ ішемічна хвороба серця й гіпертонічна хвороба.

\section{СПИСОК ЛІТЕРАТУРИ}

1. Краснова О. В. Воспоминания старых людей: рассказ историй, биография и терапия «лайф-ревью» / О. В. Краснова // Психология зрелости и старения. - 2002. № 2 (17). - С. 111-125.

2. Приходько В. Ю. Хронічні обструктивні захворювання легень у людей літнього віку. Лікування загострень / В. Ю. Приходько // Семейная медицина. - 2016. - № 1 (63). C. 82-89.

3. Петров В. Г. Лікувальна фізична культура при бронхотичній формі хронічного обструктивного захворювання легень / В. Г. Петров, О. В. Без'язична, О. В. Клітар // Фізична реабілітація та рекреаційно-оздоровчі технології. 2016. - № 2. - С. 52-53.
3. Хронічне обструктивне захворювання легень має несприятливий вплив на якість життя, включаючи емоційний та фізичний стани пацієнта, що створює необхідність активної освітньої роботи медичного персоналу з метою впливу на основні фактори ризику досліджуваної патології та коморбідних станів, що ії супроводжують.

4. Prevalence of comorbidity in patients with a chronic airway obstruction and controls over the age of 40 / J. G. van Manen, P.J. Bindels, C. J. IJzermans [et al.] //J. Clin. Epidemiol. 2001 Mar. - № 54 (3). - P. 287-293.

5. Arterial stiffness and osteoporosis in chronic obstructive pulmonary disease / R. Sabit, C. E. Bolton, P. H. Edwards [et al.] // Am J. Respir. Crit. Care Med. - 2007. - № 175. P. 1259-1265.

6. Черепій Н. В. Діагностика факторів ризику хронічного обструктивного захворювання легень за даними анкетування осіб організованого колективу / Н. В. Черепій // Вісник Вінницького національного медичного університету. - 2015. - Т. 19, № 2. - С. 448-452. 